\title{
THE TRAVELS OF A SHORT-EARED OWL EQUIPPED WITHA SATELLITE TRANSMITTER IN CANADA
}

GEOFFREY L. HOLROYD and HELEN TREFRY, Canadian Wildlife Service, Room 200, 4999-98 Ave, Edmonton, AB, T6B 2 X3.

Little is known about the seasonal or annual wanderings of Short-eared Owls in North America. Their movements appear highly motivated by the availability of food since they nest and winter in concentrations where rodents are abundant (typically voles, Microtus species, in the prairies). ${ }^{1,4}$ There also seem to be traditional areas where owls can be found in most years in summer and in winter. In winter, some Short-eared Owls disperse to the south. ${ }^{4}$ Because of their nomadism they are difficult to study using traditional techniques and little is known about their dispersal and wanderings. Houston reported no recoveries from 246 Short-eared Owls banded in Saskatchewan. ${ }^{5}$ Holt and Leasure reported 47 band recoveries in North America up to November 1992, which results indicated a south to north movement of $1,891 \mathrm{~km}$ (Oklahoma to Saskatchewan) and a north to south movement of $1,730 \mathrm{~km}$ (British Columbia to California). ${ }^{4}$

Information is needed on the dispersal behaviour of the Short-eared Owl as an important first step in the conservation of this "Vulnerable" species of "Conservation Concern" in Canada and the USA ${ }^{1,7}$ and any conservation efforts will need to incorporate all regions traversed by this species' movements. The irregular movements of these owls are impossible to follow through banding techniques.
Satellite telemetry has enabled the tracking of large mammals and birds remotely over vast distances, for instance Swainson's Hawks and Peregrine Falcons. ${ }^{3,6}$ In 2006, Microwave Telemetry Inc. introduced a 9.5 gm solar-powered platform transmitter terminal (PTT), small enough to attach to a Short-eared Owl which weighs about $350 \mathrm{gm}$ and able to operate for more than one year due to the rechargeable battery and solar panel. We attached a PTT to a Shorteared Owl on 4 November 2006 to track its movements. This was the first Shorteared Owl to be outfitted with a solar satellite transmitter in Canada and the second in the world.

The capture location was just south of Beaverhill Lake (53.37N $\left.112.58^{\circ} \mathrm{W}\right)$ $5 \mathrm{~km}$ east of Tofield, Alberta ( $65 \mathrm{~km}$ SSE of Edmonton). This area had significant numbers of wintering owls presumably resulting from high vole numbers in the winter of 2005-2006 (L. Priestley, Beaverhill Bird Observatory, March 2006 pers. comm.). We trapped the owl along a road using a live House Mouse, (Mus musculus) in a bal chatri, a wire cage covered with nooses. We weighed, measured, and confirmed that this bird was a male based on DNA taken from a feather sample. The owl weighed 355 $\mathrm{gm}$; the transmitter weighed $11 \mathrm{gm}$, or $3.1 \%$ of the owl's body weight, including the Teflon webbing harness used to attach the transmitter back-pack style. The weight guideline for 
transmitters on birds is less than 5\% of body weight. The PTT was placed on a $4 \mathrm{~mm}$ thick neoprene pad that was larger than the base of the transmitter to reduce the chance of the bird preening its feathers over the solar panel. The owl was released at the capture site at 9:16 pm after we fed it two House Mice.

The transmitter turned on during the attachment process, but failed to do so again four days later as expected by the duty cycle of the transmitter. We did not 'hear' from the transmitter until four months later at midnight on 7/8 March 2007. Unfortunately, at that time the signal was not strong enough for the satellite to provide a location, nor did it include temperature or battery voltage information. On 20 March 2007, the satellites again detected the transmitter and this time provided a location: just north of the west block of Grassland National Park, 19 km westnorthwest of Val Marie, SK $\left(49.292^{\circ} \mathrm{N}\right.$ $107.482^{\circ} \mathrm{W}$ ) and $590 \mathrm{~km}$ southeast of the trapping location. We received no further signals from the transmitter.

In early May 2007, Allison Henderson, a biologist at Grassland National Park, reported to us that local rancher Dwight Olson had handed her a strange "brown box" which turned out to be the non-functioning transmitter! Dwight had been repairing fence on his uncle's pasture about April 20 and noticed the transmitter upside down along the fence line. He saw no sign of an owl carcass when he found the transmitter, and a search of the area by us in midMay yielded no evidence of the bird.

The transmitter was found $12 \mathrm{~km}$ WNW of Val Marie and $7 \mathrm{~km}$ east of the March 20 location. This native prairie pasture, with a drainage valley full of short shrubs, appeared ideal as roosting and foraging habitat for Short- eared Owls, and suitable for voles. Across the fence was a tame pasture with tall alfalfa and weed stalks, and there were cultivated fields to the west. The original March signal had come from a larger patch of native grassland between drainage valleys.

The transmitter had two holes about $3 \mathrm{~mm}$ diameter on each side and a dent on one side. The four Teflon backpack straps were apparently bitten or cut short near the transmitter. We compared the holes in the transmitter to the canines of small mammalian predators at the Royal Alberta Museum. The fangs of a badger fit the holes perfectly. Badgers also have sharp premolars which would allow them to cut the otherwise strong Teflon webbing harness that held the transmitter on the back of the owl. We cannot be certain if the bird was killed, or scavenged after it died from some other cause.

The transmitter was placed in the direct sun on 12 May. Despite having been on the ground for up to a month, exposed to weather conditions with holes in the housing, a transmitter signal was picked up on 14 May by a passing satellite, indicating that the unit was still functioning. We returned it to the manufacturer, Microwave Telemetry, Inc. for a new housing and plan to reuse it on another owl.

Although the solar-powered transmitter did not operate during the short days of the winter, it did function the following spring as day length increased. The habit of Short-eared Owls to roost under tall grass may make it especially difficult for the transmitters to receive enough daylight to recharge. For these reasons, solar-powered transmitters may not be ideal to follow winter movements of this species. Peter Nye (New York State Wildlife Dept., November 2006, pers. comm.) 
who put the first satellite transmitter on a Short-eared Owl, had a similar experience. That transmitter transmitted on the day it was applied to an owl in winter in New York State and then again in the summer, but not in between or after. A second transmitter of the same type performed much better, sending signals through the winter and spring until late June. Since the transmitters are expected to last up to 5 years, they have the potential to allow us to track annual movements of individual Short-eared Owls.

\section{Acknowledgements}

We thank Alberta Sport, Recreation, Parks and Wildlife Foundation, Beaverhill Bird Observatory and the Canadian Wildlife Service for funding this study, and Allison Henderson and Dwight Olson for recovering the transmitter. This article benefited from comments by Jim Duncan.

1. CADMAN, M. D. and A. M. PAGE. 1994. Status report on the Short-eared Owl (Asio flammeus) in Canada. Committee on the Status of Endangered Wildlife in Canada. Ottawa, Ontario.
2. CLARK, R. J. 1975. A field study of the Shorteared Owl, Asio flammeus (Pontoppidan), in North America. Wildlife Monographs No. 47.

3. HOLROYD, G.L. and J. DUXBURY. 1999. Travels of Peregrine Falcon \#5735. Blue Jay 57 (3):146-149.

4. HOLT, D. W. and M. S. LEASURE. 1993. Shorteared Owl (Asio flammeus). In The Birds of North America, No. 62 (A. Poole and F. Gills, Eds.). The Academy of Natural Sciences, Philadelphia, Pennsylvania; The American Ornithologists' Union, Washington, D.C.

5. HOUSTON, C.S. 1997. Banding of Asio Owls in south-central Saskatchewan. In: J.R. Duncan, D.H. Johnson, and T.H. Nicholls (eds.), Biology and Conservation of Owls of the Northern Hemisphere: 2nd International Symposium. USDA Gen. Tech. Rep. NC-190, St. Paul, MN, U.S.A., pp 237-242

6. SCHMUTZ, J.K., C.S. HOUSTON and G.L. HOLROYD. 1996. Southward migration of Swainson's Hawks: Over 10,000 km in 54 Days. Blue Jay 54(2):70-76.

7. U.S. FISH and WILDLIFE SERVICE. 2002. Birds of Conservation Concern 2002. Division of Migratory Bird Management, Arlington, Virginia. [Online version available at <http:// migratorybirds.fws.gov/reports/bcc2002.pd>

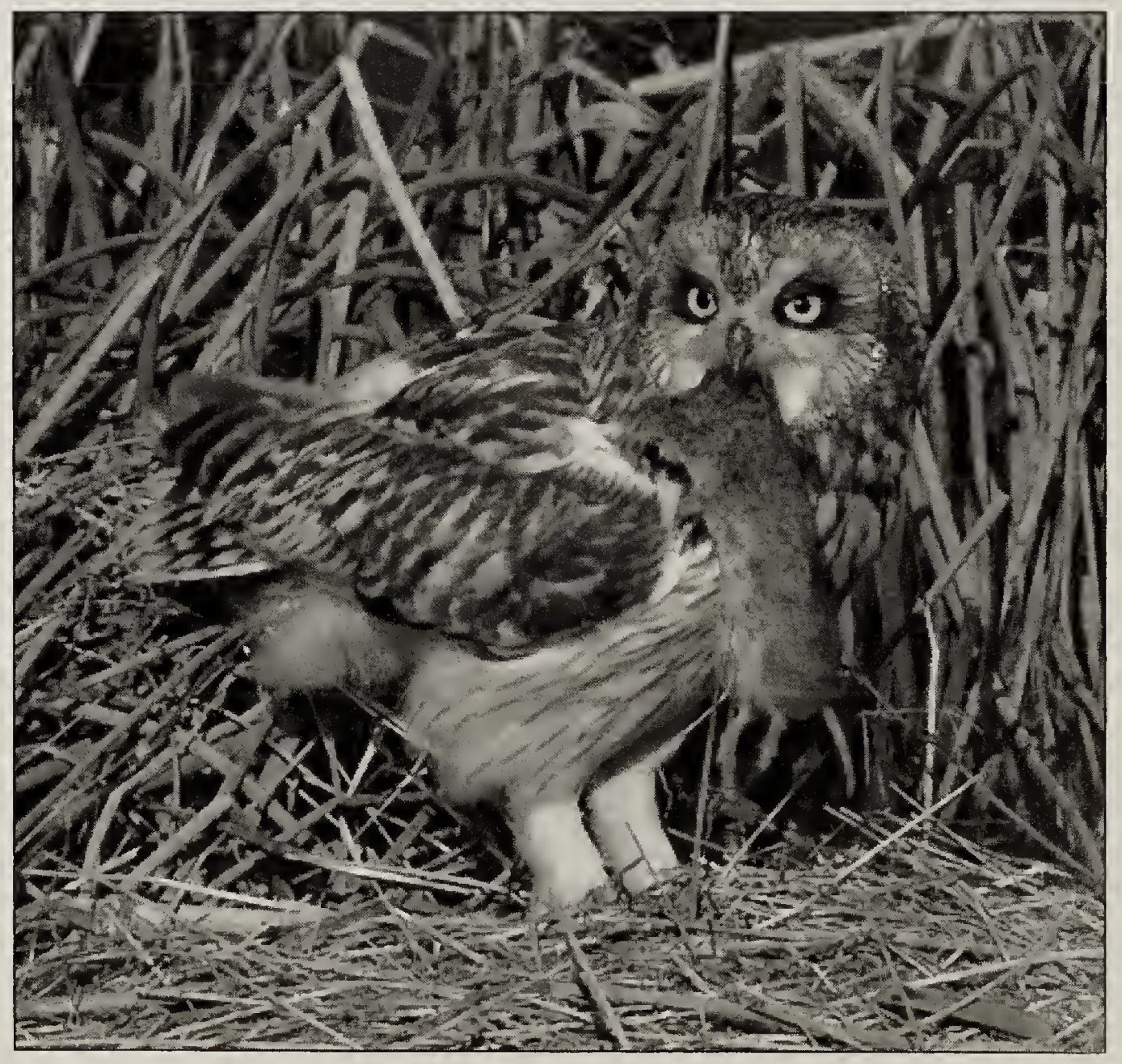

Short-eared owl with vole near Francis Lake.

Randy McCulloch 